\title{
Preface (1997)
}

As you read this preface, the Woburn case will have been going on for one-quarter of a century, since Jimmy Anderson was diagnosed with leukemia in 1972. For the 1997 printing of No Safe Place I am taking this opportunity to update some material: the incidence of leukemia, the litigation, the Department of Public Health reanalyses of data, the cleanup, and the larger impact of the Woburn case. Richard Clapp and Gretchen Latowsky have been very helpful in this task.

\section{Leukemia Incidence}

Only two new cases of childhood leukemia were diagnosed in Woburn from 1985 to the 1990s; this incidence is slightly lower than what would be expected by chance (that is, lower than the background rate) and represents a significantly smaller number of cases than was recorded when Wells $\mathrm{G}$ and $\mathrm{H}$ were operating. This additional piece of data, available in retrospect, provides evidence that the closure of the contaminated wells removed the cause of the leukemia cluster. 


\section{The Litigation}

The book ends with the rejection of an appeal of the case against Beatrice by a three-judge panel of the appellate court. Following that, the full Court of Appeals turned the case away. Jan Schlictmann asked the Massachusetts Superior Court for depositions and a bill of discovery from Mary Ryan, who had been involved in withholding Riley tannery documents. Taking the case to its final possible location, Schlictmann sought a hearing at the U.S. Supreme Court but was turned down.

\section{Department of Public Health Reanalyses}

The Department of Public Health reanalyzed the Woburn Environment \& Birth Study (WEBS) but then kept the record under wraps for several years. In 1994 the DPH reported only on reproductive disorders and birth defects and said it was still working on the leukemia reanalysis. The officials claimed they found no excess of reproductive disorders and birth defects for Woburn. However, the FACE activists, Harvard biostatisticians, and various scholars in the natural, life, and social sciences examined the DPH report. They found that the most intensive study period for the DPH was a prospective study for 1989-1991-long after the wells were closed. As a result, the citizens and their supporters believe the state continues to deny the health effects of Woburn's past contamination. They are working to obtain the DPH's data set and conduct a new reanalysis themselves.

In May 1996 the DPH released the report that detailed their reanalysis of the leukemia data: "Woburn Childhood Leukemia Follow-Up Study." The officials concurred with the Woburn activists that there was a significant doseresponse relationship $(p<.05)$ between leukemia and 
mothers' drinking contaminated water (from Wells $\mathrm{G}$ and H) during pregnancy. Some family members wept on hearing the results, and the families were pleased and vindicated by this finding.

\section{The Cleanup}

Wells $\mathrm{G}$ and $\mathrm{H}$ are being cleaned up with an air stripper which creates droplets that vaporize and remove the volatile organic compounds (VOCs) from the water, a process that is expected to produce drinkable water from those wells in fifty years. Although EPA procedures call for a cleanup, it is not clear why producing potable water is a useful thing to do; the wells have been off line for a long time and suitable water is provided from other sources. At the Industriplex site, originally thought to be the contamination source, the contaminated area has been capped to develop the site as a commercial property. The EPA touts Industriplex as a model for its "brownfields" development program, which upsets Woburn activists because they don't believe Industriplex can be sufficiently cleaned up to be useful. In particular, the site continues to leach arsenic and chromium into the Aberjona River, which distributes these substances downstream to the Mystic Lakes. Activists are also upset that the upcoming Superfund reauthorization bill may remove third party liability at cleanups, making it impossible to hold the polluting firms responsible.

\section{The Larger Impact of Woburn}

The leukemia reanalysis provided a form of closure to FACE's major public presence. As an organization, FACE has basically reverted to a grassroots organization that meets in people's kitchens. Leaders are still called by the 
DPH to review materials and other citizen groups call each week to seek advice, but FACE does not have the public presence it once did. Donna Robbins, one of the leaders, received an award from the Massachusetts Public Health Association in $\mathbf{1 9 9 6}$ for her many years of hard work on the Woburn case. Gretchen Latowsky is frequently called upon to lecture on Woburn.

Even if Woburn activists are not still in the trenches, thousands of communities around the country are fighting similar battles. In many cases, they know of Woburn and are inspired by the efforts of the residents, their lawyers, and their supporters. The toxic waste movement has become a major force in American political culture. Arising from that, environmental justice activists have emphasized the inequalities of race and class in exposure to toxic hazards, in obtaining Superfund status, and in assessment of fines against polluters.

In 1995 Jonathan Harr published his book A Civil Action, which became a bestseller. The book has been on the New York Times Paperback Bestseller List for thirty-six weeks and is now in fourth place (June, 1997). Anyone interested in the history of the Woburn cluster will find this book an exciting, well-written approach to the complex legal issues in the case, a good snapshot of many personalities, and a remarkable insight into the daily actions and feelings of Jan Schlictmann, the families' lawyer. Robert Redford purchased the film rights and work is under way on a film version starring John Travolta as Jan Schlictmann. It is amazing that a book of this sort should grab so much public attention. The fine writing of the book certainly accounts in part for its success, but more important, the book's popularity signifies that an enormous number of people sympathize with the plight of the Woburn families and that many others face a sim- 
ilar plight in contaminated communities around the country.

Studying the Woburn case had a dramatic impact on me, causing me to shift my research focus substantially from the time of my first explorations of this topic in 1985. I have written a number of articles on the further developments of toxic activism (some based on additional interviews with FACE activists, subsequent to the book research), which are listed below as part of the Bibliography for the 1997 printing.

Phil Brown

May 1997

\section{Bibliography}

Additional Studies on Woburn

Harr, Jonathan. A Civil Action. New York: Random House, 1995.

Massachusetts Department of Public Health. "Woburn Environment \& Birth Study-Synopsis." Massachusetts Department of Public Health, Bureau of Environmental Health Assessment. August 1994.

__. "Woburn Childhood Leukemia Follow-Up Study." Massachusetts Department of Public Health, Bureau of Environmental Health Assessment. May 1996.

Articles by Phil Brown on Woburn and Other Toxic Contamination Issues

Allen, Susan, and Phil Brown. "Public Reaction to Toxic Waste Contamination: Analysis of a Social Movement." International Journal of Health Services, 1990, 20:485-499. 
Brown, Phil. "The Popular Epidemiology Approach to Toxic Waste Contamination." Pp. 133-155 in Stephen Robert Couch and J. Stephen Kroll-Smith, eds., Communities at Risk: Collective Responses to Technological Hazards. New York: Peter Lang Publishers, 1991.

"Toxic Waste Contamination and Popular Epidemiology: Lay and Professional Ways of Knowing." Journal of Health and Social Behavior, 1992, 33:267-281.

Brown, Phil, and Susan Masterson-Allen. "The Toxic Waste Movement: A New Kind of Activism." Society and Natural Resources, 1994, 7:269-286.

Brown, Phil, and Faith Ferguson. "'Making a Big Stink':

Women's Work, Women's Relationships, and Toxic Waste Activism." Gender E Society, 1995, 9:145-172.

Brown, Phil. "Popular Epidemiology, Toxic Wastes, and Social Movements." Pp. 91-112 in Jonathan Gabe, ed., Medicine, Health and Risk: Sociological Perspectives. Oxford, UK: Blackwell, 1995.

. "Race, Class, and Environmental Health: A Review and Systematization of the Literature." Environmental Research, 1995, 69:15-30.

Brown, Phil, and Judith Kelly. "Physicians' Knowledge of and Actions Concerning Environmental Health Hazards: Analysis of Survey of Massachusetts Physicians." Industrial and Environmental Crisis Quarterly, 1996, 9:512-542.

Brown, Phil. "Popular Epidemiology Revisited." Current Sociology, 1997, 45:137-156.

Brown, Phil, Desiree Ciambrone, and Lori Hunter. "Does Green Mask Grey?: Environmental Equity Issues at the Metropolitan Level." International Journal of Contemporary Sociology, forthcoming. 